\title{
PENERAPAN PENDEKATAN KONTEKSTUAL DALAM PEMBELAJARAN BAHASA INDONESIA DI KELAS VII SMP PUTRA JUANG CIANJUR PADA MATERI MENULIS TEKS DESKRIPSI
}

\author{
Sindy Widia Lasifa ${ }^{1}$, Ira Arianti ${ }^{2}$ \\ ${ }^{1,2}$ IKIP Siliwangi, Jl. Terusan Jendral Sudirman, Cimahi tengah, Kota Cimahi, Jawa Barat \\ wlasifasindy@gmail.com
}

\begin{abstract}
One of the important components in education in Indonesia is the mastery of good language, Indonesian language plays an important role for education in Indonesia because it is the official language in all fields.Literary ability includes four aspects, namely: speaking, speaking, reading, and writing. Writing is one skill that has a high level of difficulty compared to other skills. Writing requires skill, extensive insight, and strong motivation to be able to help, one of the learning materials for writing in junior high school is about writing descriptive text. One alternative learning is to use contextual learning because it uses students' daily experiences as a source in writing description texts. The sample in this study was grade VII students at Putra Juang Junior High School located in the city of Cianjur, the results of the research that were refuted related to contextual application could increase the ability of students to write description texts. This is evidenced by the average value of students in learning to write text improvement description. At the first meeting the average value of students is 60 At the second meeting the average value of students is 77 . while at the first meeting only $30 \%$ of the 40 students are eligible to reach the KKM, while at the second meeting $80 \%$ of students have reached the KKM. From the results of the study it can be concluded from more effective research, which is more contextual more suitable for writing descriptive text.
\end{abstract}

Kata kunci: Contextual, Writing, Description text

\begin{abstract}
Abstrak
Salah satu komponen penting dalam pendidikan di Indonesia adalah penguasaan bahasa Indonesia, bahasa Indonesia mendapatkan peran penting untuk pendidikan di Indonesia karena merupakan bahasa resmi di semua bidang. Kemampuan bersastra meliputi empat aspek yaitu mendengarkan, berbicara, membaca, dan menulis. Menulis merupakan salah satu keterampilan berbahasa yang memiliki tingkat kesulitan yang tinggi dibandingkan dengan aspek keterampilan lainnya. Menulis membutuhkan keterampilan, wawasan yang luas, dan motivasi yang kuat untuk dapat melakukannya, salah satu materi pembelajaran menulis di SMP yaitu mengenai menulis teks deskripsi. Salah satu alternatif pendekatan pembelajaran adalah dengan pendekatan kontekstual karena menggunakan pengalaman siswa sehari-hari sebagai sumber dalam menulis teks deskripsi. Sampel dalam penelitian ini adalah siswa kelas VII di SMP Putra Juang yang terletak di kabupaten Cianjur, dari hasil penelitian disimpulkan bahwa penerapan pendekatan kontekstual dapat menigkatkan kemampuan siswa dalam menulis teks deskripsi. Hal ini terbukti dengan nilai rata-rata siswa dalam pembelajaran menulis teks deskripsi mengalami peningkatan. Pada pertemuan pertama nilai rata-rata siswa yaitu 60 Pada pertemuan kedua nilai ratarata siswa yaitu 77. dimana pada pertemuan pertama hanya $30 \%$ siswa dari 40 orang yang nilainya mencapai KKM, sedangkan di pertemuan kedua sudah $80 \%$ siswa nilainya mencapai KKM. Dari hasil penelitian dapat disimpulkan bahwa penelitian yang kedua lebih efektif, yang mana pendekatan kontekstual lebih cocok digunakan dalam menulis teks diskripsi.
\end{abstract}

Kata kunci: Kontekstual, Menulis, Teks Deskripsi.

Pendidikan merupakan proses interaksi antara pendidik dan peserta didik baik secara formal, nonformal maupun informal. Pada pendidikan formal, pembelajaran memegang peranan penting dalam membentuk siswa sebagai sumber daya manusia yang unggul untuk dapat berpikir dan bersikap kritis, logis, analisis,sistematis, kritis, dan kreatif (Bernard,2015:198, Islamiah, et. al, 2018:47). Pendidikan yang tertata dengan baik dapat menciptakan generasi yang unggul, cerdas dan berkualitas yang nantinya akan sangat berpengaruh terhadap kemajuan suatu bangsa dimasa yang akan datang. 
Salah satu komponen penting dalam pendidikan di Indonesia adalah penguasaan bahasa Indonesia yang baik dan benar karena secara umum bahasa memiliki peran sentral dalam perkembangan intelektual, sosial, dan emosional peserta didik. Bahasa merupakan penunjang keberhasilan peserta didik dalam mempelajari semua bidang studi. Pembelajaran bahasa diharapkan membantu peserta didik mengenal dirinya, budayanya, dan budaya orang lain. Selain itu, dengan bahasa peserta didik diharapkan mampu mengemukakan gagasan dan perasaan, berpartisipasi dalam masyarakat yang menggunakan bahasa tersebut, dan menemukan serta menggunakan kemampuan analitis dan imajinatif yang ada dalam dirinya. Untuk itu pembelajaran bahasa Indonesia mendapatkan peran penting untuk pendidikan di Indonesia karena merupakan bahasa resmi di semua bidang.

Pada hakikatnya, Ruang lingkup mata pelajaran Bahasa Indonesia berdasarkan Standar Kompetensi dan Kompetensi Dasar yang dirumuskan oleh Badan Standar Nasional Pendidikan (BNSP) mencakup komponen kemampuan berbahasa dan kemampuan bersastra yang meliputi empat aspek yaitu mendengarkan, berbicara, membaca, dan menulis (Permendiknas nomor 22 tahun 2006:232). Melalui aspek menulis diharapkan peserta didik memiliki kemampuan produktif atau menghasilkan sebuah karya sastra. Satu di antaranya adalah kemampuan peserta didik dalam menulis karya sastra lama yaitu pantun. Menulis merupakan salah satu keterampilan berbahasa yang memiliki tingkat kesulitan yang tinggi dibandingkan dengan aspek keterampilan lainnya. Menulis membutuhkan keterampilan, wawasan yang luas, dan motivasi yang kuat untuk dapat melakukannya. Nasucha (2019:105) menyatakan bahwa pembelajaran menulis bertujuan agar siswa terampil menulis karangan atau teks. Menulis dipandang sebagai keterampilan berbahasa yang sangat penting yang harus dikuasai oleh siswa dalam jurnal Hikmat (2009:11-20 ). Keterampilan menulis harus membutuhkan konsentrasi yang cukup baik supaya tulisan yang dihasilkan bermutu.

Teks deskripsi merupakan jenis teks yang memaparkan suatu objek, hal dan keadaan sehingga pembaca seolah-olah melihatnya dalam jurnal Lina, et., al. (2019: 102-110). Jadi jenis teks deskripsi siswa membayangkan apa yang terjadi dikehidupan nyata. Komalasari (2008:54) mengungkapkan pendekatan kontekstual menempatkan siswa dalam konteks bermakna yang menghubungkan pengetahuan awal siswa dengan materi yang sedang dipelajari dan sekaliagus memperhatikan faktor kebutuhan individu siswa dan peran guru. Pembelajaran ini guru berperan sebagai fasilitator serta mengkaitan pembelajaran dengan konteks dalam kehidupan sehari-hari.

Rahayu (2013:1-13) menyatakan pembelajaran kontekstual guru lebih memilih dalam konteks pembelajaran yang lebih tepat bagi siswanya dengan cara mengaitkan pembelajaran dengan dunia nyata dan lingkungan sekitar dimana tempat tinggal anak dan budaya yang berlaku dalam masyarakatnya. Siswa dalam memilih konteks harus diarahkan dengan pemikirannya masing-masing sehingga tidak hanya berkonsentrasi dalam pembelajaran dikelas saja, tetapi juga diajak dalam mengaitkan aspekaspek yang terjadi dikehidupan nyata mereka. Dalam pembelajaran ini siswa diberi kesempatan dalam mengonstruksikan pengetahuan dirinya sendiri dan dihubungan dengan dunia nyata sehingga peserta didik dapat memahami pelajaran dengan baik. 
Menurut Komalasari (2008:54) pendekatan kontekstual menempatkan siswa dalam konteks bermakna yang menghubungkan pengetahuan awal siswa dengan materi yang sedang dipelajari dan sekaliagus memperhatikan faktor kebutuhan individu siswa dan peran guru. Siswa dalam memilih konteks harus diarahkan dengan pemikirannya masing-masing sehingga tidak hanya berkonsentrasi dalam pembelajaran dikelas saja, tetapi juga diajak dalam mengaitkan aspek-aspek yang terjadi dikehidupan nyata mereka. Pada saat ini, penerapan pembelajaran kontekstual sering digalakkan dalam pelatihan-pelatihan dengan harapan memberikan pengaruh positif terhadap hasil belajar.

Pendekatan kontekstual merupakan salah satu alternatif pendekatan pembelajaran yang mana pendidik memposisikan para siswa sebagai subjek, bukan sebagai objek pembelajaran. Dengan kata lain, pendidik sebagai fasilitator. Pembelajaran kontekstual di kelas melibatkan tujuh komponen utama sebagaimana yang sudah ditetapkan oleh Dirjen Dikdasmen Depdiknas (2003:10-17), yaitu: 1) konstruktivime, 2) menemukan (inquiry), 3) bertanya (questioning), 4) masyarakat belajar (learning community), 5) pemodelan (modelling), 6) refleksi (reflection), 7) penilaian yang sebenarnya (authentic assessment). Berdasarkan komponen tersebut, pendekatan kontekstual diharapkan dapat membantu siswa lebih aktif dan kreatif khususnya dalam hal menulis teks deskripsi. Untuk itu penulis tertarik untuk melakukan penelitian mengenai penerapan pembelajaran kontekstual dalam mata pelajaran bahasa Indonesia pada materi menulis deskripsi pada siswa kelas VII.

\section{METODE}

Penelitian ini menggunakan metode deskriptif kualitatif dimana teknik pengumpulan data dilakukan dengan menggunakan dokumentasi, tes, dan teknik catat. Sampel dalam penelitian ini adalah siswa kelas VII di SMP Putra Juang yang terletak di kabupaten Cianjur, hal yang di teliti dalam penelitian ini adalah proses berlangsungnya pembelajaran bahasa Indonesia materi menulis deskripsi pada siswa kelas VII dengan menggunakan pendekatan Kontekstual.

\section{HASIL DAN PEMBAHASAN}

Sebelum dimulainya proses penelitian, peneliti melakukan observasi terlebih dahulu untuk mengetahui kondisi belajar siswa disekolah, serta melakukan wawancara dengan guru mata pelajaran Bahasa Indonesia di kelas VII mengenai kesulitan siswa pada materi menulis teks deskripsi. Adapun permasalahan yang ditemukan pada siswa yaitu: Siswa telihat pasif saat pembelajaran berlangsung, siswa kurang memperhatikan penjelasan guru, siswa banyak yang mengobrol dan tidak mencatat, hal ini menunjukkan proses pembelajaran kurang kondusif dan terkontrol, kemampuan siswa dalam menulis teks deskripsi terlihat masih rendah, hal ini salah satu penyebabnya karena guru terlihat hanya menyampaikan materi saja, sementara siswa jarang diberi kesempatan untuk mecoba menulis teks deskripsi dan guru sangat berpatokan pada waktu. Maksudnya bila materi yang disampaikan tidak terselesaikan pada jam pelajaran atau waktu sudah habis, maka dianggap materi sudah selesai dan guru tidak memberikan kesempatan siswa untuk mengeksplorasikan pemikirannya dalam menulis. Siswa 
yang tidak pernah menulis karna keterbatasan waktu membuat siswa itu mengalami kesulitan dalam menulis, selain itu siswa tidak diberikan tugas untuk menulis teks deskripsi. Guru juga tidak menggunakan media pembelajaran yang menarik yang dapat membantu siswa dalam memahami materi serta membuat siswa tertarik dan focus dalam mengikuti pembelajaran.

\section{Pertemuan Pertama}

Pertemuan pertama dilaksanakan pada tanggal 7 Oktober 2019 dengan jumlah jam sebanyak 2 jam pelajaran $(2 \times 40$ menit). Peneliti bertindak sebagai guru dan Ibu Dewi yang merupakan guru bertindak sebagai observer. Pada awal ini, perlunya menkoordinasi dengan guru mata pelajaran bahasa Indonesia mengenai waktu pelaksanaan pembelajaran penelitiannya. Dari hasil penelitian kemudian muncul ide sehingga peneliti mengajukan solusi alternatif yang berupa pendekatan pembelajaran yaitu pendekatan kontekstual. Berikut urutan atau langkah-langkah yang dilaksanakan pada pertemuan pertama yaitu:

1. Menyiapkan skenario dalam pembelajaran pertemuan pertama sebanyak satu pertemuan menenai materi menulis teks deskripsi dengan menggunakan pendekatan kontekstual. Pendekatan kontekstual, yang mana menggunakan pengalaman nyata individu siswa lalu dibawa ke dalam pembelajaran, maka rencana pelaksanaan pembelajaran (RPP) telah disusun dalam tujuah unsur atau komponen pendekatan kontekstual yaitu: bertanya (questioning), pemodelan (modeling), masyarakat belajar (learning community), kontruktivisme (constructivism), menemukan (inquiry), penilaian nyata (authentic assessment), dan refleksi, (reflection);

2. Membuat lembar kerja siswa (LKS) untuk evalusi pembelajaran, yang mana pada pertemuan pertama ini siswa diminta untuk mengerjakan soal yang telah dipersiapkan oleh guru.

3. Mengidentifikasi masalah belajar siswa;

4. Membuat lembar observasi dan dokumentasi

Kegiatan awal yang dilakukan setelah guru dan peneliti memasuki ruang kelas adalah mengkondisikan siswa pada situasi belajar yang kondusif serta perangkat pemebelajaran yang telah disiapkan, Kemudian membuka kegiatan pembelajaran dengan salam dilanjutkan membaca doa bersama dan mengecek absensi siswa. Guru melakukan apersepsi materi yang dipelajari pada pertemuan sebelumnya. Guru dan siswa melakukan tanya jawab tentang karangan yang pernah mereka baca di internet, majalah, buku dan koran. Siswa melakukan tanya jawab mengenai keadaan suatu tempat yang pernah mereka kunjungi dan menceritakan kepada teman-temannya secara singkat. Pelaksanaan kegiatan ini termasuk pendekatan kontekstual yaitu questioning/bertanya.

Kegiatan inti, guru menyampaikan materi mengenai teks deskripsi berupa pengertian teks deskripsi, kaidah kebahasaan dalam teks deskripsi, ciri teks deskripsi dari segi penggunaan bahasa dan ciri teks deskripsi dari segi tujuan dan objek. Siswa dibentuk kelompok, kemudian dari hasil jawaban siswa dipilih manakah yang bagus, siswa menambahi jawaban yang belum tepat. Termasuk komponen inquiry/menemukan. Siswa mengerjakan tugas mengenai materi teks deskripsi yang sudah diberikan. Kemudian hasil pekerjaanya ditukarkan ke temannya dan saling bertukar pendapat dan informasi. 
Beberapa siswa ditunjuk untuk membacakan hasil pekerjaan di depan kelas yang berhubungan dengan tempat yang pernah dikunjungi. Siswa yang ditunjuk maju bertindak sebagai model pembelajaran di depan kelas. Kegiatan ini termasuk pendekatan kontekstual yaitu komponen bertanya (questioning). Guru dan siswa bertanya jawab mengenai materi tersebut, menanyakan mengapa jawaban tersebut bisa didapat? Diperkuat dengan penjelasan dan dapat jawaban tersebut dari mana.

Sebagai kegiatan akhir pembelajaran, guru meminta beberapa siswa menyimpulkan hasil pembelajaran yang telah dilaksanakan dan guru melakukan koreksi dan menambahkan (reflection). Guru memberikan tugas latihan soal agar siswa bia lebih memahami materi yang diajarkan. Guru menutup pembelajaran dengan mengucapkan salam. Hasil observasi menunjukan bahwa terlihat siswa kurang tertib, ramai mengobrol dan bercanda dengan temen sekelompoknya, siswa kurang memperhatikan saat guru menerangkan materi dan gurupun management waktunya masih belum bisa maksimal.

Tabel 1

Hasil Ketercapaian KKM Siswa pada Pertemuan Pertama

\begin{tabular}{|c|c|c|c|l|}
\hline No. & Kode Siswa & KKM & Nilai Akhir & \multicolumn{1}{|l|}{ Keterangan } \\
\hline 1 & S-1 & 75 & 80 & Tercapai \\
\hline 2 & S-2 & 75 & 80 & Tercapai \\
\hline 3 & S-3 & 75 & 55 & Tidak Tercapai \\
\hline 4 & S-4 & 75 & 55 & Tidak Tercapai \\
\hline 5 & S-5 & 75 & 50 & Tidak Tercapai \\
\hline 6 & S-6 & 75 & 80 & Tercapai \\
\hline 7 & S-7 & 75 & 35 & Tidak Tercapai \\
\hline 8 & S-8 & 75 & 80 & Tercapai \\
\hline 9 & S-9 & 75 & 55 & Tidak Tercapai \\
\hline 10 & S-10 & 75 & 50 & Tidak Tercapai \\
\hline 11 & S-11 & 75 & 40 & Tidak Tercapai \\
\hline 12 & S-12 & 75 & 80 & Tercapai \\
\hline 13 & S-13 & 75 & 55 & Tidak Tercapai \\
\hline 14 & S-14 & 75 & 60 & Tidak Tercapai \\
\hline 15 & S-15 & 75 & 70 & Tidak Tercapai \\
\hline 16 & S-16 & 75 & 55 & Tidak Tercapai \\
\hline 17 & S-17 & 75 & 65 & Tidak Tercapai \\
\hline 18 & S-18 & 75 & 75 & Tercapai \\
\hline 19 & S-19 & 75 & 75 & Tercapai \\
\hline 20 & S-20 & 75 & 60 & Tidak Tercapai \\
\hline
\end{tabular}




\begin{tabular}{|l|l|l|l|l|}
\hline 21 & S-21 & 75 & 80 & Tercapai \\
\hline 22 & S-22 & 75 & 60 & Tidak Tercapai \\
\hline 23 & S-23 & 75 & 45 & Tidak Tercapai \\
\hline 24 & S-24 & 75 & 40 & Tidak Tercapai \\
\hline 25 & S-25 & 75 & 50 & Tidak Tercapai \\
\hline 26 & S-26 & 75 & 80 & Tercapai \\
\hline 27 & S-27 & 75 & 60 & Tidak Tercapai \\
\hline 28 & S-28 & 75 & 40 & Tidak Tercapai \\
\hline 29 & S-29 & 75 & 40 & Tidak Tercapai \\
\hline 30 & S-30 & 75 & 65 & Tidak Tercapai \\
\hline 31 & S-31 & 75 & 60 & Tidak Tercapai \\
\hline 32 & S-32 & 75 & 55 & Tidak Tercapai \\
\hline 33 & S-33 & 75 & 55 & Tidak Tercapai \\
\hline 34 & S-34 & 75 & 45 & Tidak Tercapai \\
\hline 35 & S-35 & 75 & 75 & Tercapai \\
\hline 36 & S-36 & 75 & 55 & Tidak Tercapai \\
\hline 37 & S-37 & 75 & 45 & Tidak Tercapai \\
\hline 38 & S-38 & 75 & 45 & Tidak Tercapai \\
\hline 39 & S-39 & 75 & 75 & Tercapai \\
\hline 40 & S-40 & 75 & 75 & Tercapai \\
\hline
\end{tabular}

Setelah dilakukan tes, didapati bahwa nilai siswa masih sangat jauh dibawah Kriteria Ketuntasan Minimal (KKM), yaitu 75. Siswa kelas VII berjumlah 40 siswa yang terdiri dari 8 siswa laki-laki dan 12 siswa perempuan. Dari hasil penelitian nilai rata-rata kelas adalah 60, dengan 30\% siswa yang mendapatkan nilai memenuhi $\mathrm{KKM} \geq 75$ atau 12 orang siswa, dan $70 \%$ siswa lainnya memperoleh nilai $\leq 75$, atau sebanyak 28 orang siswa belum mencapai KKM dan perlu melakukan perbaikan. Hasil pertemuan pertama digunakan dalam pembelajaran mengerjakan soal teks deskripsi masih belum efektif.

\section{Pertemuan kedua}

Pertemuan kedua dilaksanakan pada tanggal 9 Oktober 2019 dengan alokasi waktu $3 \times 45$ menit. Dengan target hasil yang diharapkan peneliti sebesar $80 \%$ siswa tercapai KKM. Pembelajaran pada pertemuan kedua ini bertujuan untuk memperbaiki kekurangan dan kelemahan yang dilakukan pada pelaksanaan pembelajaran pertemuan pertama. Peneliti dibantu oleh guru bahasa Indonesia kelas VII sebagai observer yaitu Ibu Dewi. Pada awal kegiatan, guru memasuki kelas dan mengawali pelajaran dengan mengucapkan salam, berdo'a bersama siswa dan mengecek daftar hadir siswa, dan mengecek kesiapan 
belajar siswa.

Guru memberikan games sederhana untuk menarik minat dan konsentrasi belajar siswa lalu mulai melakukan kegiatan apersepsi. Pada kegiatan inti, guru bertanya kepada siswa mengenai materi menulis teks deskripsi yang telah diajarkan pada perteuan sebelumnya, hal ini termasuk dalam komponen bertanya (questioning). Guru menjelaskan materi mengenai cara menulis teks deskripsi, ejaan teks, tanda baca teks deskripsi. Siswa mempersiapkan alat-alat tulis untuk melakukan mengarang dan guru membagikan selembaran lembar kerja siswa. Guru memberikan empat gambar yang sudah ditempel di papan tulis, kemudian siswa diminta menuliskan karangan yang sesuai berdasarkan gambar yang sudah ditempelkan. Siswa mengamati gambar yang sudah ditempel dengan cermat dan mengerjakannya tugas yang sudah di berikan oleh guru.

Secara individu siswa membuat karangan teks deskripsi secara baik dan tenang. Termasuk komponen inquiri dan konstruktivisme. Siswa membentuk kelompok yang sudah dibentuk oleh guru dan dalam diskusi tidak mengobrol diluar pembahasan materi. Salah satu kelompok tersebut dipilih pekerjaan yang baik atau hasil karangan siswa yang hasilnya maksimal untuk dibacakan di depan kelas langkah ni termasuk pada komponen pemodelan (modeling).

Kemudian hasil karya siswa tadi dikembalikan untuk diidentifikasi bersama kelompoknya. Kemudian siswa berdiskusi mengenai kesalahan apa saja yang ditemu dalam pengerjaan tugas masing-masing kelompok dan bersaha memperbaikinya, hal ini termasuk dalam komponen inquiri. Siswa yang belum paham tentang materi tersebut boleh bertanya kepada temannya satu kelompok atau kepada guru, hal ini termasuk pada komponen masyarakat belajar (learning community).

Guru melakukan bimbingan pada semua kelompok, supaya siswa dalam berkelompok ssaling bekerja sama dengan baik. Guru memberikan pengarahan kepada siswa tentang penggunaan tanda baca dan huruf kapital yang tepat di dalam suatu kalimat dan memperbaiki kesalahan-kesalahan lainnya. Guru meminta beberapa siswa menyimpulkan hasil pembelajaran pada hari terseut serta kesan dan pesan dari beberapa siswa tersebut dan uru memberi kesimpulan akhir, ini termasuk komponen refleksi (reflection), sebelum selesai pembelajaran guru meminta siswa membaca terlebih dahulu materi yang akan dipelajari pada pertemuan berikutnya, dan memberi tugas latihan soal. Dalam segi pembelajaran terlihat siswa sudah sangat tertib dan antusias dalam mengikuti pembelajaran dimana siswa terlihat sangat ktif baik secara individu maupun kelompok. Siswa senang dengan penggunaan pendekatan yang guru gunakan dan kelaspun terkelola dengan baik oleh guru dari segi waktu dan penguasaan kelas.

Tabel 2

Hasil Ketercapaian KKM Siswa pada Pertemuan Kedua

\begin{tabular}{|l|l|l|l|l|}
\hline No. & Kode Siswa & KKM & Nilai Akhir & Keterangan \\
\hline 1 & S-1 & 75 & 90 & Tercapai \\
\hline
\end{tabular}




\begin{tabular}{|c|c|c|c|c|}
\hline 2 & S-2 & 75 & 85 & Tercapai \\
\hline 3 & S-3 & 75 & 80 & Tercapai \\
\hline 4 & S-4 & 75 & 75 & Tercapai \\
\hline 5 & $S-5$ & 75 & 60 & Tidak Tercapai \\
\hline 6 & S-6 & 75 & 80 & Tercapai \\
\hline 7 & S-7 & 75 & 55 & Tidak Tercapai \\
\hline 8 & S-8 & 75 & 80 & Tercapai \\
\hline 9 & S-9 & 75 & 75 & Tercapai \\
\hline 10 & S-10 & 75 & 80 & Tercapai \\
\hline 11 & S-11 & 75 & 60 & Tidak Tercapai \\
\hline 12 & S-12 & 75 & 80 & Tercapai \\
\hline 13 & S-13 & 75 & 80 & Tercapai \\
\hline 14 & S-14 & 75 & 85 & Tercapai \\
\hline 15 & S-15 & 75 & 80 & Tercapai \\
\hline 16 & S-16 & 75 & 85 & Tercapai \\
\hline 17 & S-17 & 75 & 80 & Tercapai \\
\hline 18 & S-18 & 75 & 80 & Tercapai \\
\hline 19 & S-19 & 75 & 80 & Tercapai \\
\hline 20 & S-20 & 75 & 85 & Tercapai \\
\hline 21 & S-21 & 75 & 85 & Tercapai \\
\hline 22 & S-22 & 75 & 80 & Tercapai \\
\hline 23 & S-23 & 75 & 85 & Tercapai \\
\hline 24 & S-24 & 75 & 70 & Tidak Tercapai \\
\hline 25 & S-25 & 75 & 75 & Tercapai \\
\hline 26 & S-26 & 75 & 85 & Tercapai \\
\hline 27 & S-27 & 75 & 80 & Tercapai \\
\hline 28 & S-28 & 75 & 65 & Tidak Tercapai \\
\hline 29 & S-29 & 75 & 80 & Tercapai \\
\hline 30 & S-30 & 75 & 80 & Tercapai \\
\hline 31 & S-31 & 75 & 85 & Tercapai \\
\hline 32 & S-32 & 75 & 75 & Tercapai \\
\hline 33 & S-33 & 75 & 80 & Tercapai \\
\hline 34 & S-34 & 75 & 75 & Tercapai \\
\hline 35 & S-35 & 75 & 80 & Tercapai \\
\hline 36 & S-36 & 75 & 80 & Tercapai \\
\hline
\end{tabular}




\begin{tabular}{|l|l|l|l|l|}
\hline 37 & S-37 & 75 & 55 & Tidak Tercapai \\
\hline 38 & S-38 & 75 & 55 & Tidak Tercapai \\
\hline 39 & S-39 & 75 & 70 & Tidak Tercapai \\
\hline 40 & S-40 & 75 & 85 & Tercapai \\
\hline
\end{tabular}

Dari hasil penelitian didapatkan bahwa rata-rata nilai siswa adalah 77, siswa yang mendapatkan nilai mencapai KKM atau $\geq 75$ adalah 32 (80\%). Sedangkan 8 siswa lainnya (20\%) memperoleh nilai $\leq 75$, perlu melakukan perbaikan. Sehingga siswa yang mencapai KKM dapat dikatakan berjumlah 32 siswa. pendekatan kontekstual efektif dan cocok untuk digunakan dalam menulis teks deskripsi sehingga siswa sangat nyaman dalam mengikuti pembelajaran dan nilai yang dicapainya memuaskan.

Dari hasil penelitian dapat diketahui bahwa pembelajaran dengan menerapkan bukan hanya berasal dari guru, melainkan juga didukung oleh keaktifan siswa selama pelaksanaan kegiatan pembelajaran, sehingga pemahaman pada menulis lebih mudah dipahami oleh siswa.Berdasarkan data nilai hasil belajar siswa kelas VII SMP Putra Juang selama proses penelitian mengalami peningkatan. Hal ini ditandai dengan rata-rata nilai peserta didik dan banyak peserta didik yang belum mencapai KKM. Sehingga dapat diajukan bahwa melalui pendekatan kontekstual sangat efektif untuk meningkatkan kualitas proses dan kualitas hasil pembelajaran menulis karangan deskripsi pada peserta didik. Maka dari itu dapat dikatakan bahwa melalui pembelajaran kontekstual yang mengacu pada dunia nyata yang dibawa ke dalam dunia pembelajaran sangat membantu peserta didik dalam meningkatkan keterampilan menulis, meningkatkan daya nalar serta pengalaman baru bagi peserta didik terhadap menulis teks deskripsi. Hal ini sejalan dengan hasil penelitian sebelumnya yang dilakukan oleh (Hayati, 2019; Umar \& Martono, 2014)

\section{KESIMPULAN}

Berdasarkan penelitian yang dilaksanakan dua kali pertemuan dalam upaya meningkatkan keterampilan menulis teks deskripsi melalui pendekatan kontekstual pada siswa kelas VII SMP Putra Juang tahun ajaran 2019/2020, dapat disimpulkan bahwa penerapan pendekatan kontekstual dapat menigkatkan kemampuan siswa dalam menulis teks deskripsi. Hal ini sudah terbukti bahwa penelitian pada pertemuan pertama mendapatkan nilai terendah yaitu 35 dan nilai tertinggi yaitu 80 .

Pada pertemuan kedua nilai terendah yaitu 55 dan nilai tertinggi yaitu 90. Selain itu, pada rata-rata dalam pembelajaran menulis teks deskripsi mengalami peningkatan. Pada pertemuan pertama nilai rata-rata siswa yaitu 60 Pada pertemuan kedua nilai rata-rata siswa yaitu 77. Dan apabila dilihat dari tingkat ketuntasan belajar siswa menurut KKM, terlihat jelas perbedaan yang sangat signifikan dimana pada pertemuan pertama hanya $30 \%$ siswa dari 40 orang yang nilainya mencapai KKM, dsedangkan di pertemuan kedua sudah $80 \%$ siswa nilainya mencapai KKM. 
Dari hasil penelitian dapat disimpulkan bahwa penelitian yang kedua lebih efektif, yang mana pendekatan kontekstual lebih cocok digunakan dalam menulis teks diskripsi. Implikasi dalam penelitian menggunakan metode kontekstual dengan melaksankan tujuh komponen dapat memberikan pengaruh yang positif terhadap proses pembelajaran pada siswa dalam mengikuti pembelajaran menulis khususnya dalam menulis teks deskripsi yang harus dikembangkan dalam pembelajaran Bahasa Indonesia.

\section{DAFTAR PUSTAKA}

Bernard, M. (2015). Meningkatkan kemampuan komunikasi dan penalaran serta disposisi matematik siswa SMK dengan pendekatan kontekstual melalui game adobe flash cs 4.0.Infinity Journal, 4(2), 197-222.

Depdiknas. 2006. Panduan Penyusunan Kurikulum Tingkat Satuan Pendidikan Jenjang Pendidikan Dasar dan Menengah. Jakarta : BSNP

Hayati, H.N., \& Yakub N., (2019). Penerapan Metode Kontekstual Keterampilan Menulis Teks Deskripsi dalam Pembelajaran Bahasa Indonesia Kelas VII SMP Negeri 2 Sawit (Doctoral dissertation, Universitas Muhammadiyah Surakarta).

Hikmat, A. (2015) "Peningkatan Kemampuan Menulis Cerpen Melalui Pendekatan Pembelajaran Kontekstual Pada Mahasiswa Prodi Bahasa Indonesia FKIP UHAMKA". Kajian Linguistik dan Sastra, 21(1):11-20

Islamiah, N., Purwaningsih, W. E., Akbar, P., \& Bernard, M. (2018). Analisis Hubungan Kemampuan Pemecahan Masalah Matematis dan Self Confidence Siswa SMP. Journal on Education, 1(1), 47-57.

Komalasari, K. (2010). Pembelajaran Kontekstual Konsep dan Aplikasi. Bandung: PT Refika Aditama. Lina, Tiawati, R., Dwinitia, S. (2014). "Implementation of Instructional Explicit Model Toward Writing Skill of Descriptive Text for Junior High School Student”. Jurnal Bahasa, 1(2): 102-110.

Nasucha, Y. (2019). Metode Pembelajaran Dalam Pendekatan Pilabah Teori dan Implementasi Pembelajaran Kooperatif. Surakarta: Yua Pustaka.

Permendiknas Nomor 20 Tahun 2007 tentang Standar Penilaian pendidikan pada point B butir 8 .

Sukmadinata, N.S. (2011). Metode Penelitian Pendidikan. Bandung: Remaja.

Umar, H. S., \& Martono, H. (2014). Pendekatan Pembelajaran Kontekstual untuk Kecakapan Menulis Pantun pada Mata Pelajaran Bahasa Indonesia. Jurnal Pendidikan dan Pembelajaran, 3(11). 